\title{
Todos somos migrantes
}

Todos nosotros en algún momento de nuestra vida nos alejamos del lugar en el cual ya no nos sentimos integrados, consideramos que permanecer en él, es continuar un viaje de abandono de nosotros mismos sin retorno, por eso nos resistimos a seguir allí y con mucha fuerza acompañada de nostalgia, por dejar a nuestros seres queridos, -que imposible sería integrar en la maleta- decidimos partir del terruño.

Al llegar al otro país se contribuye al cambio de escenario social que hasta el momento permanecía, se incrementan las demandas de servicios públicos, se transforma la población, se transmuta la cultura y en definitiva, habrá que aceptar que se conforma una nueva realidad social.

Pero, qué es lo que pasa con el país de origen y con el país receptor, cómo deben organizarse y ser mejores para lograr un equilibrio en el desarrollo y crecimiento de toda su población, cómo alcanzar el necesario abastecimiento de servicios públicos, cómo garantizar a todos los habitantes de ese territorio receptor el respeto por los derechos humanos de esa nueva sociedad demandante.

Para ello hay que tener en cuenta que la migración no solo influye en la evolución y crecimiento personal sino que llega a trastocar los aspectos sociales, económicos y culturales tanto del país de origen como del país de acogida, ambos ganan y ambos pierden.

Se gana cuando se reciben remesas millonarias, -de enero a noviembre del año pasado el Banco Mundial estimó la llegada a México de 26,167 millones de dólares- y también se gana cuando se obtiene mano de obra barata y se conforma una especie de "subcategoría" de trabajador que no reclama servicios de calidad como el resto de los ciudadanos; y desde luego, si contribuye al desarrollo económico del país al que se ha incorporado, se estima que viven 3 millones de indocumentados en Estados Unidos que están con el riesgo y la zozobra de ser deportados y 9 millones de inmigrantes, son en total 12 millones de Mexicanos que han decidido emigrar para mejorar su situación económica y la de sus familias. 
Se pierde, porque sufre la administración publica del país receptor al no poder planificar presupuesto "para los otros", y también se pierde porque en el país de origen se genera la separación de familias que afecta a regiones enteras.

Si esto es así, si la repercusión de la migración se sufre a escala nacional, bilateral y multilateral, entonces me pregunto ¿por qué no se gestionan políticas públicas que generen desarrollo y prosperidad desde el país de origen que confluyan en el país de destino?, ¿Por qué no interesa ofrecer la posibilidad de gozar del derecho humano que todos tenemos, a una vida en paz, con seguridad, libertad y justicia en cualquier lugar de residencia? ¿Por qué parece que los países receptores se quejan del flujo incontrolable de ciudadanos que llegan de otros lugares y sin embargo se siguen beneficiando de la mano de obra barata al atribuirles trabajos de segunda y tercera categoría -denominados así por el esfuerzo que requiere para llevarlo a cabo y la poca remuneración que se obtiene-?.

Indudablemente, ante el fracaso de la administración publica Estatal y de los acuerdos bilaterales e internacionales, el único que pierde es el ciudadano inmigrante, con la carga de sufrimiento y deterioro emocional invisible que lleva a cuestas.

Cualquiera que sea el lugar, el contexto y el punto de vista desde donde se mire, el desplazamiento de personas es un fenómeno inmemorial que responde a una necesidad, la mayoría de las veces de supervivencia y desarrollo humanitario.

Por lo tanto, en un mundo globalizado el problema no solo debe ubicarse en la persona del inmigrante, por haber nacido en el lugar inadecuado que lejos de favorecer el libre desarrollo de una vida digna, coexiste en un ambiente de pobreza y corrupción que no garantiza sus derechos humanos. Él abandona el territorio y la comunidad en donde nace como una salida que le promete el acceso a una vida más prospera.

El problema entonces va mas allá y tiene que ver con la legitimación del Estado de origen, pues tal parece que no sabe, no quiere o no puede dar solución a los problemas de desarrollo social y económico de sus propios habitantes, lo cual lo coloca en un serio cuestionamiento de su razón de ser. 
También el problema es del Estado que recibe a miles y miles de personas y a cambio de la mano de obra barata pretende menospreciar y abusar del débil y necesitado, violentando los derechos humanos.

La acción tripartita marca la solución, estrategias colectivas dentro de un derecho global podrían ser la clave para este grave malestar social.

Es importante que la comunidad internacional elabore un esquema de organización, planeación y distribución de la riqueza en el mundo, enfocada a perpetuar el respeto de los Derechos Humanos.

Hoy en día el Estado-Nación en muchos de sus fundamentos ha sido rebasado, por lo tanto si el Estado de origen resulta insuficiente pidamos un cambio en las políticas públicas, organicémonos, colaboremos todos los ciudadanos, hagamos todo lo que está en nuestras manos para exigir un cambio para que el Estado de origen asuma la responsabilidad y el Estado receptor deje de negar los derechos humanos del desvalido inmigrante argumentando razones de nacionalidad.

Otoño 2018

Dra. Silvia Patricia López González

Directora-Editora 
